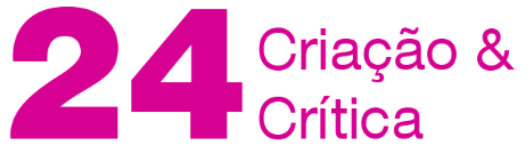

\section{E QUANDO O SUBALTERNO FALA?: IDEOLOGIA, TRADUÇÃO E ÉTICA}

\author{
Pedro Trindade Auad ${ }^{1}$
}

\begin{abstract}
RESUmo: Este artigo parte do seminal texto de Gayatri Chakravorty Spivak, Pode o Subalterno Falar? para refletir sobre as impossibilidade de fala, mas também de escuta. Para tal abordagem, retomamos as discussões sobre ideologia presentes na obra da teórica indiana e seus desdobramos sobre o problema do subalterno. Assim, sendo um problema que se inscreve na linguagem, acionamos teóricos com afinidade com a autora, notadamente Judith Butler e Jacques Derrida, para pensarmos sobre os paradoxos que nascem tanto em certa sujeição ideológica quanto na apropriação da linguagem. Nesse sentido, chegamos ao problema da tradução, entendida como um procedimento social e ético. A tradução, assim, se torna condição necessária para que o subalterno tenha alguma possibilidade de fala.
\end{abstract}

PalAVRAS-chave: Ideologia. Teoria pós-colonial. Tradução. Spivak. Ética.

\section{AND WHEN DOES THE SUBALTERN SPEAK?: IDEOLOGY, TRANSLATION AND ETHICS}

ABSTRACT: This article is based on the seminal text by Gayatri Chakravorty Spivak, Can the Subaltern Speak? to reflect on the impossibility of speech, but also of listening. For such approach, we return to the discussions of ideology presented in the work of the Indian scholar and unfold the problem of the subaltern. Being a problem that is inscribed in language, we relate thinkers with affinity with the author, notably Judith Butler and Jacques Derrida, to think about the paradoxes that emerge in ideological subjection as in the appropriation of the language. In this sense, we address the problem of translation, understood as a social and ethical procedure. The translation, therefore, becomes a necessary condition for the subaltern has the possibility to speak.

KEYWORDS: Ideology. Postcolonial theory. Translation. Spivak. Ethic.

Em um dos textos mais importante da teoria literária feminista dos anos 1970, Dancing Through the Minefield, de Annette Kolodny, a teórica afirma que a literatura das mulheres não seria qualificada como boa o suficiente para adentrar o cânone porque a formação de leitores seria falha em criar outras possibilidades de leitura a não ser aquelas que já estavam constituídas e que retificavam o que era considerada uma grande obra. Assim, existiria uma "uma incapacidade de predominantemente criar leitores para interpretar e apreciar textos de mulheres - devido, em grande parte, a uma falta de conhecimento anterior" (KOLODNY, 1997, p. 179). Poder-se-ia identificar em seu texto a criação de uma barreira ideológica que impediria um certo tipo de interpretação desses trabalhos que poderiam revelar outras formas de leitura do objeto literário, construindo novos paradigmas e novas afecções.

Essa falta de "capacidade" de leitura, entretanto, em boa parte foi sendo contornada, mesmo que de maneira periférica, para a interpretação da literatura daquelas obras elididas do cânone, predominantemente de grupos subalternizados. Constantemente, também, se

1 UFMG, pedroauad@gmail.com 


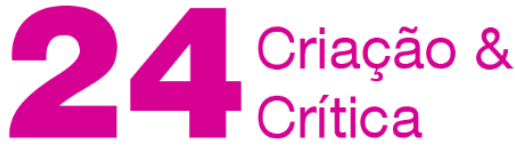

retoma o texto de Gayatri Spivak, Pode o Subalterno Falar? como ponto de inflexão sobre a exclusão desses trabalhos do grupo dos considerados grandes trabalhos que teriam certo apuro estético e, por isso, sendo altamente valorosos. O discurso que pretende que se tenha uma certa imanência estética "boa" em obras acaba por elidir da história outras possibilidades estéticas, relegando obras a um segundo plano ou, ao menos, à espera que um olhar pouse os olhos sobre essa obra desvendando outras camadas e outros valores. O problema quando isso acontece é que, não necessariamente, esses outros olhares são o suficiente para que as obras entrem no panteão das grandes obras, clássicos ou, mesmo, do cânone.

Neste trabalho retomo o texto supracitado de Spivak como ponto de partida para a discussão de que a superação dessas barreiras talvez esteja muito mais em uma ética do que em uma dimensão só estética ou moral. Isso porque o problema que se coloca no texto da crítica e teórica indiana é, antes de mais nada, um problema da ideologia. A partir da retomada dessa importante inflexão teórica adentraremos outras possibilidades que se abrem tanto em sua obra quanto nas de Jacques Derrida e Judith Butler, principalmente. É a partir disso que chegaremos na tradução, mas pensaremos em uma espécie de tradução que chama uma relação com a ética. É em uma relação ética que seria possível pensar na questão que colocamos: e quando o subalterno fala?

Lidando com obras que, querendo ou não, tocam o feminismo e também em questões de gênero, chamo atenção ainda para aquilo que Claudia de Lima Costa constata a respeito desse trabalho que também se esforça em uma espécie de tradução:

Dado seu caráter interdisciplinar, teorizar no feminismo implica desde já engajar-se em tradução - traduzir conceitos e terminologias de um campo disciplinar para as categorias analíticas de outro(s) em um processo que Gayatri Spivak caracteriza como "transação dinâmica de leituras", ou seja, o ato de colocar uma forma de teorizar em contato ou transação com outra na leitura de qualquer tipo de texto, literário ou social. Nos resvalos resultantes desse encontro de linguagens, textos e significados, e a partir de traduções necessariamente infiéis, faz-se possível a construção de outros "mapas relacionais do conhecimento". (COSTA, 2003, p. 1)

\section{O subalterno não pode falar e a ideologia}

Apesar de ser muito tentador tentar responder a pergunta quase retórica de Spivak com o último parágrafo de seu texto Pode o Subalterno Falar?, acho necessário, antes, um recuo, para poder localizar, exatamente, de onde surge a sua resposta. Nessa conclusão, a teórica indiana afirma que "o subalterno não pode falar", mas acrescenta que seria porque não haveria valor algum atribuído à "mulher" (as aspas são dela) e que a "representação não definhou" e que caberia à mulher intelectual uma tarefa "circunscrita que ela não deve rejeitar com um floreio" (SPIVAK, 2010, p. 126).

A afirmação de que o subalterno não pode falar não aconteceria porque ele não fala no sentido estrito do termo, ou seja, que ele não enuncia nada, mas vem de um outro lugar que é o da representação e que, doravante, vai ser colocado como uma questão da ideologia. E é 


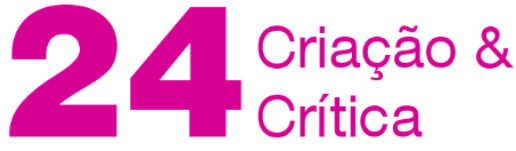

por ignorar a questão da ideologia que surge a problematização que ela realiza de dois filósofos franceses alocados na categoria de pós-estruturalistas, a saber, Gilles Deleuze e Michel Foucault. Spivak vai destacar que o discurso de que as massas sabem muito bem sobre seus desejos, ou como Foucault vai destacar em conversa com Deleuze intitulada de Os intelectuais e o poder - "Ora, o que os intelectuais descobriram recentemente é que as massas não necessitam deles para saber; elas sabem perfeitamente, claramente, muito melhor do que eles; e elas o dizem muito bem" (FOUCAULT, 1989, p. 71) - acaba ignorando a "ideia de contradição constitutiva" (SPIVAK, 2010, p. 28) e que leva a uma ausência da "necessidade da difícil tarefa de realizar uma produção ideológica contra-hegemônica" o que acabaria auxiliando certo empirismo subjetivista "a definir sua própria arena como a da 'experiência concreta', 'o que realmente acontece'” (SPIVAK, 2010, p. 30).

É em relação crítica a esse posicionamento que a teórica indiana vai retomar a distinção que Karl Marx realiza em seu $O 18^{\circ}$ Brumário entre vertreten e darstellen, entre representar e re-presentar, respectivamente. Ainda, na distinção entre essas duas formas de representação, a primeira se apresentaria no contexto político enquanto a segunda no contexto econômico. Em certo sentido, poder-se-ia dizer que enquanto representar se caracterizaria por uma forma de "falar por", o segundo se daria de forma indireta, mas ainda como uma "variedade de dominação" (SPIVAK, 2010, p. 42), que perpassaria a prática econômica capitalista.

De certa maneira, a divisão aqui poderia ser entre o conceito de ideologia do primeiro Marx e o conceito de ideologia que deriva do Marx científico, principalmente de O Capital, divisão esta que Paul Ricœur entende como o entendimento de ideologia enquanto "imagem invertida" da realidade e aquela que estaria mais presente em um autor como Althusser em que "a pretensão do sujeito de ser aquele que dá sentido à realidade (Sinngebung) é precisamente a ilusão de base" (RICCEUR, 2015, p. 22).

Ao ignorar essas distinções da representação - que não poderiam permitir ao sujeito subalterno uma total clareza sobre si - o que acabaria acontecendo seria uma espécie de "violência epistêmica", que ainda mantém uma relação entre o Eu e o Outro (principalmente o Outro da Europa), que se valeria de uma total ignorância da divisão internacional do trabalho (inclusive o intelectual). Assim,

De acordo com Foucault e Deleuze (falando a partir do Primeiro Mundo, sob a padronização e regulamentação do capital socializado, embora não pareçam reconhecer isso), os oprimidos, se tiverem a oportunidade (o problema da representação não pode ser ignorado aqui), e por meio da solidariedade através de uma política de alianças (uma temática marxista em funcionamento neste caso), podem falar e conhecer suas condições. Devemos agora confrontar a seguinte questão: no outro lado da divisão internacional do trabalho do capital socializado, dentro e fora do circuito da violência epistêmica da lei e educação imperialistas, complementando um texto econômico anterior, pode o subalterno falar? (SPIVAK, 2010, p. 54) 


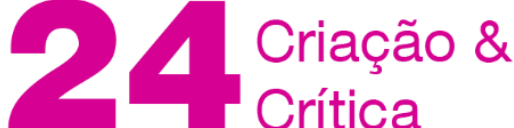

É necessário retomar essa perspectiva antes de simplesmente selecionar a "resposta" que Spivak oferece à sua pergunta logo ao final de seu artigo. Enfim, temos um problema que é de ideologia em uma aproximação com Marx e a pergunta fora desse contexto obscurece 0 complemento da resposta, a saber, a questão da representatividade que ainda não definhou e a responsabilidade da intelectual diante dos textos, em especial da intelectual mulher. É interessante notar, nesse sentido, que Spivak não está em uma tradição "canônica"² que o conceito de ideologia despertou entre diversos marxistas, com o sentido "forte" do termo, tal qual Noberto Bobbio definiu, que seria ligado, "desde Marx, a uma distorção no conhecimento" (KONDER, 2002, p. 10). Ou seja, mesmo quando ressalto a importância para a discussão que Spivak engendra a partir de Marx não é para "encaixá-la" dentro de certa tradição marxista (muito europeia). Se fosse para colocá-la em uma linha de atuação não será em Lukács ou Goldman, mas em certa tradição da ideologia que poderia passar por Althusser mas, principalmente, naquela desperta dentro dos Estudos Culturais ou dos estudos pós-coloniais, como em Stuart Hall, que, justamente, interrompem a interpretação "forte" do termo ou, como nas palavras do jamaicano, "trabalhar na vizinhança do marxismo, sobre o marxismo, contra o marxismo, com ele e para tentar desenvolvê-lo" (HALL, 2011, p. 191).

Sabendo que a representatividade ainda exerce uma importância significativa, seria importante entender a qual tipo de representatividade a teórica indiana é mais incisiva em sua crítica e dentro da representatividade como poderia a intelectual se portar de maneira contrahegemônica. Não seria simplesmente abrindo mão de qualquer representatividade, mas, claramente, de não achar que se está falando por alguém. Ao mesmo tempo, o outro regime de representatividade deveria ser utilizado para denunciar as próprias amarras que faz com que o subalterno não possa falar. Nas palavras de Spivak, ainda é importante "o intelectual que não abdica de si mesmo" (SPIVAK, 2010, p. 122). Entretanto, o subalterno ainda não poderia falar e acredito que em dois sentidos: não é permitido a fala e, ao mesmo tempo, quando o subalterno fala ele não seria compreendido.

\section{Antígona: um paradigma}

Esse último sentido que ressalto acima parece ser o ponto da releitura que a teórica estadunidense Judith Butler realiza das teorias da ideologia de Althusser em um livro inteiramente dedicado ao que ela chama de teorias da sujeição, $A$ vida psíquica do poder. É voltando ao clássico trabalho do franco-argelino, Ideologia e Aparelhos Ideológicos do Estado, que Butler vai trabalhar com a ideia de sujeição e com a ideia de ideologia. Ela nos lembra

\footnotetext{
2 Estamos atentos, também, que além da exclusão das teorias feministas das discussões sobre a ideologia que tem como um dos pontos altos a inclusão do texto Feminismo, ideologia e desconstrução: uma visão pragmática, de Richard Rorty, na antologia sobre o tema Uma mapa da ideologia, organizada por Slavoj Žižek, em que não consta nenhum texto de alguma feminista -, é sabido também, como Gayle Rubin argumenta em Políticas do Sexo, a dificuldade de encontrar qualquer parte da agenda feminina dentro do grande esquema tradicional que deriva de Marx \& Engels. Entretanto, sabemos que, como a maioria das feministas materialistas que surgem a partir principalmente dos anos 1960, é, senão em um método, ao menos uma certa leitura de Marx contribui, também, para as teorias feministas.
} 
que, para Althusser, "a eficácia da ideologia consiste, em parte, na formação da consciência, sendo a 'consciência' entendida como o que coloca restrições ao que é dizível, ou, sem sentido amplo, representável" (BUTLER, 2017, p. 123) e, assim, "Althusser associa o surgimento de uma consciência em geral - e de uma consciência 'cívica e profissional' [la conscience civique et professionnelle] - com o problema de falar apropriadamente" (BUTLER, 2017, p. 123).

Dessa forma, uma das maneiras que a sujeição ocorreria seria justamente quando a pessoa aceita falar de determinada maneira, dentro dos padrões esperados da sociedade, mas não só de uma forma ampla, mas também aceitando as suas posições e classes. Dentro dessa perspectiva, argumenta Butler, a submissão e o domínio exercido pela ideologia ocorreriam simultaneamente e "nem a submissão nem o domínio são performados pelo sujeito; a simultaneidade vivida da submissão como domínio, e do domínio como submissão, é a condição de possibilidade para o surgimento do sujeito" (BUTLER, 2017, p. 125).

A autora de $A$ vida psíquica do poder, entretanto, não parece satisfeita com as conclusões de Atlhusser já que não seria possível nenhuma escapatória porque quando a pessoa se tornaria sujeito ela também já se submeteria à ideologia. Por isso, ela articula a sua leitura de Althusser à perspectiva que Mladen Dolar também realiza do texto Ideologia e Aparelhos Ideológicos do Estado. Nessa outra leitura, a ideologia - que perpassaria por rituais da sociedade - teria uma capacidade produtiva e não somente a produção indiscutível do sujeito e o sujeito poderia reivindicar um espaço, pequeno que seja, para que a submissão não faça desaparecer completamente o ser social. Assim, um fracasso na interpelação da fala poderia "enfraquecer a capacidade do sujeito de 'ser' em um sentido idêntico a si mesmo, mas também pode marcar o caminho rumo a um tipo de ser mais aberto e até mais ético, do futuro e para o futuro" (BUTLER, 2017, p. 140). Assim, entre a impossibilidade da saída ideológica porque já fundada na própria apreensão da fala e da linguagem, se abre uma possibilidade para que se possa ser diferente daquilo que se é.

A vida psíquica do poder foi lançado em 1997. Três anos depois Butler publica O Clamor de Antígona, livro em que vai se centrar na mitológica figura grega e refletir sobre questões éticas. Chamo este livro aqui por Antígona ser, de alguma forma, essa personagem que rompe com a submissão imposta pela linguagem e mesmo não sendo nem considerada cidadã na Grécia Antiga, por ser mulher, ela reivindica o lugar de defender o direito da família, oposto ao direito da cidade. Ou seja, é uma não cidadã que vai interpelar Creonte, aquele que detém a justiça porque tirano. Antígona é uma figura importante nesse sentido não só pelo enfrentamento ao poder constituído, mas também porque é alguém que se apropria da linguagem do poder para poder confrontá-lo ou, dizendo de outra maneira, ela não fala apropriadamente porque ela não fala como se esperaria de uma mulher não-cidadã, apesar de falar como os homens de poder. Esse jogo paradoxal que Antígona impõe à linguagem é o que causaria a fissura durante a trama estabelecida por Sófocles: o uso da linguagem do direito para ir de encontro a ele.

Como é sabido, Hegel e Lacan realizam uma leitura da ética a partir de Antígona e é nisso que Butler vai se concentrar inicialmente. Então, pergunta a autora do livro: "que tipo de discurso político é esse que transgride os próprios limites do político, que põe em escandaloso 
movimento o limite pelo qual o discurso de Antígona deveria ser contido?" (BUTLER, 2014, p. 21). O problema colocado aqui, como dito anteriormente, é um problema da linguagem, do discurso e quando Antígona se endereça a Creonte, "ela se torna masculina; ao ser implicado na fala, ele se desmasculiniza, assim nenhum dos dois mantém sua posição dentro do gênero, e a perturbação do parentesco parece desestabilizar o gênero durante a peça" (BUTLER, 2014, p. 29). Assim,

O seu ato é de linguagem. Tornar público o próprio ato pela linguagem é, de certa forma, a conclusão do ato, bem como o momento que a implica no excesso masculino chamado húbris. $E$ assim, quando começa a agir pela linguagem, ela também se desvia de si mesma. Seu ato nunca é completamente seu; embora ela use a linguagem para reivindicar seu feito, para afirmar sua autonomia "masculina" e rebelde, ela só pode realizar esse ato incorporando as normas do poder aos quais ela se opõe. De fato, o que confere a esses atos verbais o seu poder é a operação normativa de poder que eles encarnam, mesmo sem se realizar inteiramente. (BUTLER, 2014, p. 29)

E, por fim, "Antígona se afirma a si mesma apropriando-se da voz do outro, aquele a quem ela se opõe; assim, sua autonomia é conquistada através da apropriação da voz autorizada daquele a quem resiste, uma apropriação que traz consigo traços de uma simultânea recusa e assimilação dessa própria autoridade" (BUTLER, 2014, p. 30).

Antígona instaura uma crise no reino de Creonte, seu tio, que ofereceu uma cerimônia honrosa para o morto Etéocles, defensor de Tebas, ao passo que deixa Polinice apodrecer a céu aberto, já que invasor da cidade. Estes são irmãos de Antígona, filhos de Jocasta e Édipo, que por sua vez é esposo da mãe. Nessas relações de parentesco um tanto tempestuosas, Antígona ainda era noiva de Hêmon, seu primo, filho de Creonte. E essa crise, seguindo os passos de Butler, não é somente uma crise entre as leis da família e a lei do Estado, mas também uma crise na linguagem instaurada no paradoxo que Antígona impõe a partir de seu ato de fala, como supracitado. O paradoxo pode ainda ser acentuado: o subalterno só poderia falar caso ele assumisse a voz do outro e, consequentemente, perdesse a própria? A superação do conteúdo ideológico que faz com que o subalterno não possa falar seria justamente aquele que faz com que ele não fale?

É certo aqui que Antígona não pode falar, mas, entretanto, ela fala e, mais, ela coloca em crise justamente a submissão a que é infligida a partir do momento mesmo que adquire a capacidade da linguagem ou de como falar de maneira apropriada para quem você é no meio da sociedade. Entretanto, ela instaura uma crise que não é só a partir da língua, mas também, como destaca Butler (2014, p. 43), uma crise que "é a própria função representativa, o próprio horizonte de inteligibilidade em que opera e de acordo com o qual permanece, de certa forma, impensável". Ora, se é a representação que ainda existe e que faz com que o subalterno não possa falar, como apontava Spivak, temos em Antígona uma possibilidade.

Butler é ainda mais otimista: 


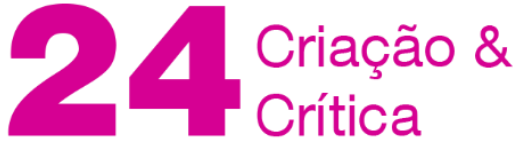

Antígona é a ocasião para um novo campo do humano, conquistado através da catacrese política, que ocorre quando o menos que humano fala como humano, quando o gênero é deslocado e o parentesco afunda em suas próprias leis fundadoras. Ela age, fala e se torna alguém cujo ato de fala é um crime fatal, mas essa fatalidade excede sua vida e adentra o discurso de inteligibilidade como sua própria fatalidade promissora, a forma social de seu futuro aberrante, sem precedentes (BUTLER, 2014, p. 114).

Obviamente é difícil esperar que surjam Antígonas em todos os lugares e instâncias. Não que isso fosse indesejável, mas é difícil pensar que todas as pessoas subalternizadas teriam a capacidade de utilizar uma linguagem que não é necessariamente sua principalmente porque negam a elas o acesso - para se impor contra a lei que, justamente, a silencia, até porque o acesso a essa linguagem, digamos, do direito é restrito e não amplificado. Não haveria alguma outra solução, alguma outra possibilidade? Seria possível fugir do circuito ideológico sem ter que se atrelar necessariamente a ele?

\section{Paradoxos da língua}

Algumas orientações do teórico franco-argelino Jacques Derrida a respeito da questão da língua podem nos ajudar a enredar uma possibilidade de fuga, marcando que o paradoxo do uso da língua de Antígona se acentua e demonstra que não é somente ela que age paradoxalmente, mas todo aquele que fala. Ou, dizendo de outra forma, Antígona exporia o paradoxo da linguagem, que Derrida vai destacar, enquanto Creonte seria apenas aquele que tenta sustentar o seu lugar de poder e ignora sua própria contradição: a sua húbris. Expõe Derrida esses paradoxos: "Sim, eu não tenho senão uma língua, ora ela não é minha" (DERRIDA, 2016, p. 25) e, acrescenta "1. Não se fala nunca senão uma única língua. 2. Não se fala nunca uma única língua" (DERRIDA, 2016, p. 31).

Tais paradoxos, ou, como diz ironicamente, "contradições performativas", indicariam não que não existisse uma certa relação de domínio entre o colonizador e o colonizado ou entre quem defende a hegemonia e aqueles que são empurrados para fora do campo hegemônico, para usar expressões mais próximas de Spivak. Não, esses paradoxos indicam que o hegemônico subtrai a língua dos outros e a coloca como se fossem naturais, "porque o amo e senhor não possui como próprio, naturalmente, aquilo a que, no entanto, ele chama a sua língua" e, acrescenta:

Porque não pode acreditar e dizer esta apropriação senão no decurso de um processo não natural de construções político-fantasmáticas; porque a língua não é o seu bem natural, ele pode por isso mesmo historicamente, através da violação de uma usurpação cultural, quer dizer, sempre de essência colonial, fingir apropriar-se dela para impor como "sua". (DERRIDA, 2016, p. 50). 


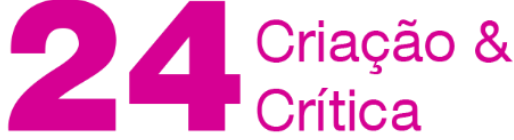

Derrida faz algumas referências não muito incisivas sobre a ideologia ao longo de seu texto, algumas vezes citando outro termo: a hegemonia. Mas, mesmo não falando de ideologia propriamente dita, sua posição contra a língua dos senhores e dos amos aparenta bastante àquilo que Butler vai desenvolver como tarefa contra-ideológica e marxista ainda na introdução de seu Problemas de Gênero: "expor os atos contingentes que criam a aparência de uma necessidade natural, tentativa que tem feito parte da crítica cultural pelo menos desde Marx" (BUTLER, 2010, p. 59). Dizendo de uma maneira ainda mais clara: apontar que aquilo que é considerado natural como sendo uma construção cultural seria o primeiro passo para uma posição contra-ideológica e, assim, poder-se-ia abrir um espaço que seja para que ninguém se poste como dono da língua e da linguagem. Nesse sentido, esse paradoxo que Antígona desvela, a partir da leitura de Butler, já seria um ato político, mas essencialmente ético por ser colocado como uma relação entre aqueles que falam e a apropriação e reapropriação de uma língua.

Antes, é importante destacar que tanto Problemas de Gênero, quanto Pode o Subalterno Falar? são livros que foram inscritos em meio a uma crise feminista em que poderiam ser incluídos outros livros importantes como o Manifesto Ciborgue de Donna Haraway, por exemplo. Todos livros que, de alguma maneira, tentam lidar com a questão de que mulheres não se sentiriam representadas pelo feminismo de então. É desse momento de crise que a noção de gênero à la Butler surge e que, também, Spivak sentenciaria que o subalterno não pode falar. De todo modo, é importante acompanhar o desdobramento que se segue daí: se Butler vai repensar inicialmente as categorias que formalizam o sujeito e parte para um estudo sobre a sujeição e para a ética, Spivak vai seguir diversos outros caminhos, mas dois chamam nossa atenção - a tradução e a ética. E é em um estudo sobre a ética e a educação que ela vai afirmar: sim, o subalterno pode falar, mas sem deixar de alimentar ainda um novo paradoxo.

\section{Quando o subalterno fala}

Isabelle Stengers faz uma crítica em relação a quem acha que é suficiente apontar que algo não é natural, mas socialmente construído: "assim, quando ressoa o eterno refrão, 'vocês acham que isso "existe", no sentido em que isso teria direito de se impor a nós, mas isso não passa na verdade de uma construção social', não se produz nenhum sentido de 'possíveis' repentinamente liberados. Tudo parece dito, mas nada é produzido". (STENGER, 2015, p. 105). Concordamos com ela quando ela afirma que a crítica que se interrompe à constatação de uma construção social de algo que é tido como "natural", como fizemos acima, é insuficiente para lidar com o problema. No máximo se torna possível circunscreve-lo, apontá-lo, nomeá-lo; e o nosso problema aqui talvez seja ainda outro: e quando o subalterno fala?

Em Ethics and politics in Tagores, Coetzee, and certain scenes of teaching, Spivak se propõe a pensar sobre ética e política, mas retendo de Kant a descontinuidade entre a ética e a política e de Levinás a descontinuidade entre a ética e a epistemologia. Nesse sentido, ela pensa a ficção não só como um evento, mas como tarefa [task], o que remeteria àquela tarefa do intelectual que cita em seu Pode o Subalterno Falar?. E qual seria essa tarefa? "Restaurar 


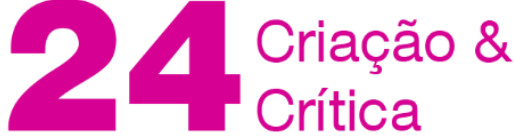

a referência para que a intertextualidade possa funcionar; e de criar intertextualidade também" (SPIVAK, 2012, p. 319). Nesse sentido, ela se debruça sobre o livro Desonra de J. M. Coetzee, criando uma intertextualidade entre ele e um poema de Rabindranath Tagore ["Meu país desgraçado, você terá que ter igual desgraça para todos e cada um que vocês desgraçaram milenarmente"], mas também entre o livro do sul-africano e Rei Lear de Shakespere e $O$ Processo, de Kafka. Por exemplo, o nada que Cordélia reafirma ao longo da peça do inglês, remeteria ao "nada, mas", de Lucy, personagem do livro, que poderíamos remeter ainda ao poema As três palavras mais estranhas, de Wisława Szymborska: "Quando pronuncio a palavra Nada, / crio algo que não cabe em nenhum ser" (SZYMBORKA, 2011, p. 107).

Esse processo de intertextualidade evidenciaria que o texto "dá sinais retóricos ao leitor, o que leva a ativar a imaginação leitora. A literatura advoga nesse sentido especial. (...) Se as ciências sociais descrevem as regras do jogo, a literatura ensina como jogar" (SPIVAK, 2012, p. 323). Spivak vai entender que a focalização, termo que ela acha mais apropriado do que perspectiva ou ponto de vista, em Desonra, é confinada a David Lurie, professor universitário acusado de assédio a uma aluna e que, por outro lado, Lucy, sua filha, é constantemente negada a focalização. Assim, o leitor nunca poderia ficar satisfeito com a insucesso de sua leitura e esse sinal retórico deveria ser um indício para o leitor contra-focalizar [conterfocalize]. A "provocação para a contrafocalização é o 'político' na ficção política - a transformação de uma tendência em crise" (SPIVAK, 2012, p. 324). Spivak sabe perfeitamente bem que nem todo leitor diante de um texto como Desonra teria a capacidade de decifrá-lo, com todas as intertextualidades que ela engendra em sua leitura, como ela o faz, ainda mais com uma percepção sobre a contrafocalização. Assim, seria tarefa do professor ou pesquisador, ou mesmo do intelectual, de toda forma, de algum tutor, de dividir os passos que o levou a realizar determinada leitura.

Spivak, então, se debruça brevemente no texto de Herculine Barbin, uma hermafrodita do século XIX que deixou um diário, publicado por Foucault, antes de cometer suicídio. É falando sobre esse texto que Spivak retoma o seu Pode o Subalterno Falar?:

Eu apresentei Pode o Subalterno Falar? como um artigo vinte anos atrás. Nesse artigo eu sugeria que o subalterno não poderia [could not] "falar" porque, na ausência da agência validada institucionalmente, não haveria o sujeito da escuta. Minha escuta, separada pelo tempo e pelo espaço, era talvez um impulso ético. Tem de haver presumidamente um coletivo de pessoas que escutam e sujeitos que contra-assinam e agentes na esfera pública para que o subalterno possa "falar". (SPIVAK, 2012, p. 326).

Spivak vai argumentar que, através da contrafocalização presente em Desonra, o subalterno fala, mas não porque é dado "voz" a ele, ainda mais porque Lucy não é, em nenhum momento, focalizada, mas porque ele desnuda os próprios instrumentos que fazem com que o subalterno não possa falar.

Que escolha curiosa a de Spivak de retomar o seu texto justamente para dar exemplo do subalterno que fala em Desonra que, mesmo sendo um texto sul-africano, foi escrito por 


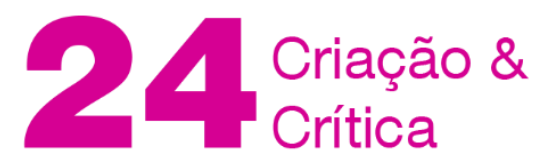

um homem branco, totalmente inserido dentro das tradições da literatura anglo-saxã! É importante aqui ressaltar que o subalterno fala não porque tem as suas falas impressas no papel ou o seu jeito de falar ou mesmo sua "visão de mundo" ou valores ou moral. Não, o subalterno fala aqui porque os procedimentos adotados pelo autor do texto, ou seja, a contrafocalização, coloca em crise certa ideologia que tende a ter como natural que não se escute o outro que fala. Em outras palavras, o subalterno fala quando o mecanismo é utilizado para demonstrar os próprios processos do silenciamento em que a focalização de um sujeito acaba apagando outros sujeitos não majoritários. Enfim, a crise é como posta na leitura que Butler faz de Antígona: uma crise que se dá na linguagem e nos procedimentos adotados por Coetzee em seu romance.

Nesse sentido, o subalterno fala não em um sentido que sua voz e jeito de falar ou mesmo valores estão imprimidos em um texto, como poderíamos supor que aconteceria nas obras de William Faulkner ou Guimarães Rosa ou mesmo João Antônio, por exemplo. Ou que ele fala simplesmente quando é uma voz minoritária a escrever, tal como poderia acontecer com as obras de Carolina Maria de Jesus, Alice Walker ou Chimamanda Ngozi Adichie - que produziram obras incríveis -, ou de qualquer outra pessoa subalternizada pelo mundo que pode ser considerada "boa" não importando sua qualidade, mas por ser, simplesmente, "uma voz subalterna falando" - algo inclusive que Spivak (2006) chega a caracterizar como sendo uma atitude racista dos críticos. Não, o subalterno falaria quando expõe ao leitor as modalidades de silenciamento, através de uma crise, em que, por exemplo, a contrafocalização faz com que percebamos que aquele subalternizado, ali, não fala. Em outras palavras, poder-se-ia quase chegar aqui a um novo paradoxo: o subalterno fala quando se mostra o porquê de ele não falar.

De certa forma a questão levanta por Spivak - pode o subalterno falar? - nesse contexto se aproxima quase do paradoxo da própria ideologia - para retornar ao nosso ponto de partida -, como Ricœur reconhece, a partir da leitura de Ideologia e Utopia, de Karl Mannheim:

O paradoxo reside na impossibilidade de aplicar o conceito de ideologia a ele mesmo (...) A extensão do próprio conceito marxista de ideologia fornece o paradoxo da reflexividade do conceito, segundo o qual a teoria se torna uma parte de seu próprio referente. Ser absorvido, ser engolido por seu próprio referente, este talvez seja o destino do conceito de ideologia" (RICCEUR, 2015, p. $23-24)$.

Se o subalterno só pode falar ao se exibir a maquinaria que o impede de falar ou ao mostrar o seu impedimento de falar, a crítica à ideologia que manifesta esse silenciamento é, no limite, uma crítica que também se interrompe e que exibe a maquinaria de seu impedimento crítico. Um paradoxo que levanta a pergunta de Alfredo Bosi quando relê também a obra de Mannheim: "quem pode proferir juízos de valor fora ou acima do seu próprio nicho social?" (BOSI, 2010, p. 75).

Mas Spivak, também, nos redimensiona uma outra possibilidade em seu texto, quando ela retoma, resumidamente, o seu Pode o Subalterno Falar?. Ela afirma que depende não só 


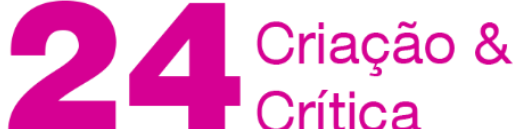

do ato de fala do subalterno para que ele fale, mas que é necessário, também, aquele que escuta, o receptor dessas mensagens. Mas não um receptor qualquer que apenas escuta e que pode, simplesmente, ignorar tudo que foi dito. E, mais, não é suficiente só uma pessoa escutar: é necessário criar um grupo de pessoas que estejam escutando esse subalterno, pessoas que contra-assinem junto com o subalterno o seu texto e agentes que façam parte da esfera pública que compartilhem as maneiras do subalterno. Ou seja, não basta o subalterno falar: ele tem que ser escutado, tem que estar junto, mas ser também participante. Eu me pergunto se, de alguma maneira, o subalterno não falaria em um livro como Memórias de um rato de hotel, de Arthur Antunes Maciel (Dr. Antônio), o ladrão que João do Rio encontrou em um presídio no Rio de Janeiro e do qual ele é o ghost writer de sua história. Sem entrar em pormenores do problema de autor e autoria aqui, é interessante notar que a contra-assinatura se torna explicita e presente, mas, por outro lado, quem escutou a história do Dr. Antônio e o quanto a esfera pública a debateu e a acolheu, um livro que foi, e ainda é, ignorado quase que completamente pela crítica, diferentes de outros livros de João do Rio?

A minha sugestão a seguir é que esses pressupostos para que o subalterno fale, sem ser no tipo de paradoxo exposto acima, está em outro lugar, que seria em uma ética a partir da tradução, entendida aqui não no sentido estrito do termo, mas um sentido amplo. Parto para isso porque, para quem segue a produção de Spivak, percebe a importância fundamental que teorias da tradução adquirem em sua obra, perpassando não só questões linguísticas, mas também políticas e éticas.

\section{Uma tradução ética}

Antes de adentrar nas posições de Spivak, se torna importante voltar ao texto de Derrida supracitado em que ele realiza o seguinte comentário:

Uma necessidade que existe e que opera portanto: a tradução, uma outra tradução que não aquela de que falam a convenção, o sentido comum e alguns doutrinários da tradução. Porque, essa dupla postulação,

- Não se fala nunca senão uma língua

(sim mas)

- Não se fala nunca uma única língua...

não é somente a própria lei daquilo a que se chama a tradução. Seria a própria lei como tradução. (DERRIDA, 2016, p. 34)

Derrida amplia o conceito estritamente linguístico da tradução para colocá-la como uma operação cultural, que constrói uma outra lei. Derrida, tal como Spivak vai sair da posição de enunciação da palavra para o lugar de escuta, invertendo, no que chama de "monolinguismo do outro", a tradução para o receptor, ou seja, existiria uma língua de chegada, aliás, não existiria "senão uma língua de chegada ou antes de porvir, uma frase prometida, uma língua do outro, ainda, mas absolutamente diferente da língua do outro como língua de senhor ou de colono, ainda que ambas possam por vezes anunciar entre si, mantendo em segredo ou 
guardando de reserva, tantas semelhanças perturbantes" (DERRIDA, 2016, p. 112). E é no processo de tradução que a crise expõe que ninguém é dono de uma língua: "tradução de uma língua que não existe ainda, e que não terá nunca existido, numa língua dada à chegada" (DERRIDA, 2016, p. 116). Não dá para não achar semelhanças no texto de Derrida com o Butler supracitado em ao menos um ponto: a língua colocada em crise por Antígona seria a possibilidade para um futuro - um futuro aberrante, como colocaria Butler - e Derrida faz a promessa de uma língua que ainda não existe, uma língua que vai ser construída não por aqueles que se consideram donos dela, senhores dela, mas uma língua que será construída e constituída como um lugar para onde se pode ir, nesse messianismo derridiano. Enfim, a tradução, entendida nesse sentido amplo, é uma promessa, uma promessa de futuro. Se a ética é a forma em que pensamos sobre como conviver o eu e os Outros, essa seria uma língua ética, já que pressupõe o compartilhamento de um espaço inteligível entre o eu e o Outro.

Spivak é tradutora de Derrida: foi a responsável pela tradução em inglês de Gramatologia, uma das produções mais importantes do franco-argelino, e escreveu um texto em que foca nesse processo tradutório, Translation into English. Mas gostaria de me focar aqui em outro texto: The politics of translation. Nele, Spivak ainda não coloca a tradução como uma possibilidade de futuro, mas identifica que em um processo de tradução é necessário a criação de vários pontos de relações entre o texto original e o texto traduzido, ou texto original e sua sombra, como ela nomeia. Ela afirma que um texto produz relações entre lógica e retórica, entre gramática e retórica e pontua que essas relações, doravante, são também "relações entre a lógica social, razoabilidade social, e a desorganização da figuração na prática social" (SPIVAK, 1993, p. 209), bem como essa retórica irá apontar para "a possibilidade de aleatoriedade, a contingência como tal, disseminação, o desmoronar da linguagem, a possibilidade de que as coisas podem não ser sempre semioticamente organizadas" (SPIVAK, 1993, p. 209).

Chamo atenção para o fato de que, em uma tradução, para Spivak, as relações em jogo não são simplesmente relações de linguagem - retórica, gramática e lógica -, mas também de outros tipos de relação que perpassarão pelas relações sociais, razoabilidade e das figurações das práticas sociais e que, diante de um texto traduzido, há uma erupção de impossibilidades e dificuldades entre o texto original e sua sombra. Spivak também chama a atenção para algo que irá denominar de "silêncio retórico" (SPIVAK, 1993, p. 205): não é mais aquilo que é dito, mas aquilo que intencionalmente não é colocado nos textos originais e ao que, nem sempre, os tradutores estão atentos.

Apesar de o que está exposto acima ser um resumo bastante rápido do que Spivak discute em seu texto (inclusive com exemplos), o que interessa sublinhar é que ela, tal como Derrida, tem uma percepção da tradução como algo mais amplo do que a simples transplantação de uma língua para outra. Para ela, mesmo quando se está fazendo a conversão entre as línguas, não há só uma questão de caráter linguístico, mas de uma relação que é, também, política. Essa relação entre o texto "original" e sua sombra aponta, inclusive, para recursos retóricos que podem estar presentes no silêncio, naquilo que não se fala. $O$ silêncio - não o silenciamento, para que fique claro - é também um paradoxo da própria fala, 


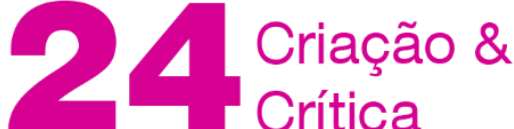

da escrita, em que se fala e se "oculta", silêncio que performatiza os outros paradoxos já engendrados que foram discutidos neste texto. Chamo atenção aqui para o problema da tradução como um problema de relação e, como ela pontua em outro texto, "a ética não é um problema do conhecimento mas um chamamento para a relação" (SPIVAK, 2012a, p. 233). A tradução é um problema que chama a ética e a ética chama a relação. Ou, ainda, a ética é uma relação.

Robert Eaglestone (2005, p. 137), no texto Levinas, Translation e Ethics, afirma que toda a postura ética de Levinas é, também, um problema de tradução, tradução do Outro, daquele que não compreendemos: "Levinas argumenta que a responsabilidade ética sem fim (portanto, infinita) é uma incumbência de cada um de nós. A contraintuitiva conclusão é que nós somos responsáveis por aqueles que nós não compreendemos ou que não podemos ou poderíamos compreender". Seria possível pensar que o encontro com o Outro, com o rosto do próximo, a partir da fala do subalterno, ou mesmo da literatura dos subalternizados, como uma espécie de encontro com a palavra-rosto ou linguagem-rosto? Porque, como Levinas define em sua obra, o rosto seria aquele primeiro momento de uma responsabilidade: "tenho descrito sempre o rosto do próximo como portador de uma ordem, que impõe ao eu, diante do outro, uma responsabilidade gratuita - e inalienável, como se o eu fosse escolhido e único e o outro homem é absolutamente outro, isto é, ainda incomparável e, assim, único" (LEVINAS, 2014, p. 28). Mas a relação não é só de encontro, de contato. Como Derrida vai destacar bem, além desse encontro, a relação, em Levinas, também é uma relação de acolhimento: "é preciso pensar sobretudo a possibilidade do acolhimento para pensar o rosto e tudo o que se abre ou se desloca com ele" (DERRIDA, 2004, p. 43) e, acrescenta, "o acolhimento determina o 'receber', a receptividade do receber como relação ética" (DERRIDA, 2004, p. 43). Se ética é uma relação, ela não é apenas uma relação intransitiva, mas uma relação do acolhimento e da receptividade.

Se Spivak abre outra possibilidade para que o subalterno possa ser escutado, sem ser a própria crise dessa possibilidade como aconteceria em Desonra, o que temos em sua obra é uma mudança de foco: se antes a questão insidiava no dito subalterno e nas amarras ideológicas que fazem com que ele não possa falar, agora, poder-se-ia pensar numa possibilidade de que a questão pode ser colocada em uma perspectiva diferente. Não é que o subalterno não fale nada, o problema é a relação do que ele fala com aqueles que o escutam, é um problema de quem recebe o texto (seja falado, seja escrito) do outro, aquele não disposto a uma tradução e, também, nem um pouco disposto a estabelecer uma relação. Portanto, poder-se-ia pensar na necessidade de uma imposição ética, de acolhimento do texto do outro, do texto subalternizado, daquela palavra-rosto ou linguagem-rosto. Em outras palavras: o subalterno só fala se ele é escutado, em uma língua ainda por vir, para retomar a promessa de Derrida. Isso talvez explique a insuficiência, apesar da enorme importância, de que simplesmente se abra espaço para que grupos subalternizados falem: não é o suficiente, apesar de necessário, mas poderia ser sempre mais se fosse aberto algum espaço para a escuta, tradução, para a criação de uma relação. 


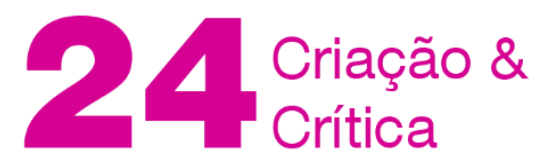

Se o problema da tradução, para Spivak, incide em uma relação entre o texto original e sua sombra, entre um "original" e uma "sombra", ainda teríamos aqui não uma questão de substituição ou de um espaço que só possa ser ocupado entre o eu ou o Outro. A tradução ética aqui irrompe naquilo que Butler vai ler, justamente, na obra de Levinas: "se algo me substitui ou toma meu lugar, isso não significa que esse algo passa a existir onde outrora eu existi, tampouco que eu deixo de existir, muito menos que me dissolvi no nada em virtude de ser substituída de alguma maneira. Em vez disso, a substituição indica que uma transitividade irredutível, uma substituição que não é um ato único, acontece o tempo todo" (BUTLER, 2015, p. 118-119).

\section{Algumas considerações finais}

Spivak e Butler lançaram juntas um livro intitulado Who sings the Nation-State. Nessa conversa entre as duas teóricas, ao se pensar no hino mexicano quando cantado nos Estados Unidos da América, se destacavam as palavras somos iguales. Butler se pergunta se esse ato discursivo - "que não apenas declara de forma audaz a igualdade do nós, mas também demanda uma tradução para ser entendido - não instala a tarefa da tradução no coração da nação" (BUTLTER \& SPIVAK, 2007, p. 66). Butler pondera que algumas vezes se torna necessária uma espécie de tradução para que se entenda a própria nação ou construção nacional e que a igualdade dentro dessa própria nação só seria possível com algum grau de fissura e não com uma homogeneização. De certa forma, o que Butler argumenta é que o mito da nação, no mundo contemporâneo, só poderia funcionar através de uma espécie de tradução (ou trabalho de tradução) a partir de uma "metáfora dissonante" que exporia as contradições e as fissuras da nação. O que Butler e Spivak discutem aqui, justamente, são as implicações ideológicas que estão inscritas na própria tradução, tradução esta, no sentido lato, que as duas estão realizando do hino mexicano.

Se o problema ideológico ainda persiste, é preciso retomá-lo para fazer algumas considerações finais. Como visto, a ideologia seria um mecanismo poderoso que impediria o subalterno falar, mas ela não seria também um mecanismo brutalizador que nos impede de escutar? Spivak, em seu texto original, nos diz de uma tarefa, de uma responsabilidade do intelectual. Apesar de dizer dessa tarefa, a teórica não explicita como ela se daria ou qual o seu programa, a não ser a partir da elucidação da intertextualidade, que penso que poderia ser uma espécie de tradução, inclusive do texto literário, nesse sentido mais amplo. Assim, uma das tarefas do crítico, do teórico, até mesmo do intelectual, seria a da tradução adotada por uma perspectiva ética, do Outro, uma ética fundada na relação e na transitividade, em que não se tenta realizar um apagamento ou substituição, mas uma elucidação. Em outras palavras: o subalterno nunca vai falar se, também, não for incluída aí uma escuta tradutória. Isso deveria ser incluído naquilo que Derrida (1994, p. 25) chama de "responsabilidade da língua", em seu livro sobre os fantasmas de Marx.

Sugiro ainda, aqui, que uma segunda responsabilidade em relação ao problema ético e ao problema ideológico é o reconhecimento que a ideologia é também minha e não só do 


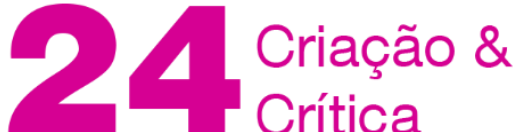

outro ou como Alfredo Bosi vai colocar: "o intelectual vive no interior da sua ideologia (...), mas pode ter consciência dos limites conjunturais a que está sujeito, o que lhe permite reagir ao particularismo estreito da sua situação cultural e buscar a compreensão de outros pontos de vista, desenhando-se em sua mente o horizonte de uma totalidade virtual” (BOSI, 2010, p. 81). Somente dentro de limites que se sabe que se tem é que poderia surgir uma brecha para além das crises impostas pela língua, pela linguagem, pela ideologia, e para o problema do subalterno falar: uma brecha, que, inclusive, teria que transpor os nossos próprios paradigmas de leitura e estética.

\section{Bibliografia}

BOSI, A. Ideologia e contraideologia. São Paulo: Companhia das Letras, 2010.

BUTLER, J. Problemas de gênero: feminismo e subversão da identidade. Rio de Janeiro: Civilização Brasileira, 2010.

BUTLER, J. O clamor de Antígona: parentesco entre a vida e a morte. Florianópolis: Editora da UFSC, 2014.

BUTLER, J. Relatar a si mesmo: crítica da violência ética. Belo Horizonte: Autêntica, 2015.

BUTLER, J. A vida psíquica do poder: teorias da sujeição. Belo Horizonte: Autêntica Editora, 2017. BUTLER, J.; SPIVAK, G. Who sings the Nation-State? Language, politics, belongins. Londres, Nova York, Calcuta: Seagull Books, 2007.

COSTA, C. As publicações feministas e a política transnacional da tradução: reflexões do campo. Revista Estudos Feministas. vol.11 no.1 Florianópolis Jan./Jun. 2003.

DERRIDA, J. Espectros de Marx. Rio de Janeiro: Relume-Dumará, 1994.

DERRIDA, J. O monolinguismo do outro. Belo Horizonte: Chão de Feira, 2016.

DERRIDA, J. Adeus a Emmanuel Levinas. São Paulo: Perspectiva, 2004.

EAGLESTONE, R. Levinas, translation, and Ethics. In: BERMANN, S. \& WOOD, M. Nation, Language, and the Ethics of Translation. Oxfordshire: Princeton University Press, 2005.

FOUCAULT, M. Microfísica do Poder. Rio de Janeiro: Edições Graal, 1979.

HALL, S. Estudos culturais e seu legado teórico. In: HALL, Stuart. Da diáspora: identidades e mediações culturais. Belo Horizonte: Editora UFMG, 2011. p. 187-204.

KOLODNY, A. Dancing Through the Minefield. In: HERNDL, D.; WARHOL, R. Feminisms. Hampshire: Macmillan Press, 1997.

KONDER, L. A Questão da ideologia. São Paulo: Companhia das Letras, 2002.

LEVINAS, E. Violência do rosto. São Paulo: Edições Loyola, 2014.

RICCEUR, P. A ideologia e a utopia. Belo Horizonte: Autêntica, 2015.

RORTY, R. Feminismo, ideologia e desconstrução: uma visão pragmática. In: ŽlŽEK, S. (Org.). Um mapa da ideologia. Rio de Janeiro: Contraponto, 1996. P. 227-234.

RUBIN, G. Políticas do Sexo. São Paulo: Ubu, 2017.

SPIVAK, G. The Politics of translation. In: SPIVAK, G. Outside in the Teaching Machine. Nova York \& Londres: Routledge, 1993. 


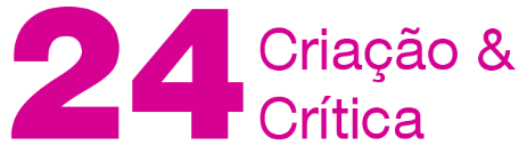

SPIVAK, G. Conversations with Gayatri Chakravorty Spivak. Londres, Nova York, Calcutta: Seagull Books, 2006.

SPIVAK, G. Pode o subalterno falar? Belo Horizonte: Editora UFMG, 2010.

SPIVAK, G. Ethics and Politics in Tagore, Coetzee, and Certain Scenes of Teaching. In: SPIVAK, G. An Aesthetic education in the era of globatization. Cambridge, Londres: Harvard University Press, 2012. pp. 316-334.

SPIVAK, G. Echo. In: SPIVAK, G. An Aesthetic education in the era of globatization. Cambridge, Londres: Harvard University Press, 2012a. pp. 218-240.

SPIVAK, G. Translation into English. In: SPIVAK, Gayatri Chakravorty. An Aesthetic education in the era of globatization. Cambridge, Londres: Harvard University Press, 2012a. pp. 256-274. STENGERS, I. No tempo das catástrofes. São Paulo: Cosac Naify, 2015. SZYMBORSKA, W. [poemas]. São Paulo: Companhia das Letras, 2011.

Recebido em: 27/04/2018 Aceito em: 15/06/2018

Referência eletrônica: AUAD, Pedro Trindade. E quando o subalterno fala?: Ideologia, tradução e ética. Criação \& Crítica, n. 24, p., out. 2019. Disponível em: $<$ http://revistas.usp.br/criacaoecritica>. Acesso em: dd mmm. aaaa. 